\title{
Analysis of Factors Affecting Edmodo Adoption as Learning Media Using Technology Acceptance Model 2 (TAM 2)
}

\author{
Randy Pradana Kushatmaja ${ }^{1}$ and Erma Suryani ${ }^{2}$
}

\begin{abstract}
Electronic-based learning media is essential in the industrial revolution 4.0 era for the advancement of education. Electronic learning (E-Learning) like Edmodo has an important role to support the practice of teaching and learning at universities. Edmodo was chosen as the one of the most effective User Generated Content (UGC) to directly represent users between lecturers and students. The ease and benefits of using Edmodo have never been measured at Ciputra University, Indonesia. Edmodo must be analyzed in order to determine the acceptance and benefits perceived by users. Distribution of samples was conducted using an online questionnaire as the data collection method. The data analyzed were obtained from 94 respondents using descriptive statistics and path analysis. Respondent data were processed using the SPSS software. Technology Acceptance Model 2 (TAM 2) is the most suitable method in analyzing the user acceptance adoption based on its constructs. This study used 10 constructs which had been adjusted to answer problems and focus on explanatory research to measure user acceptance with a quantitative approach. The result indicated that the relationship of the highest indicator with a value of $35 \%$ is on the Output Quality (X4) which had a significant effect on Perceived Usefulness (Y1); the lowest indicator has a value of $3.1 \%$ on the Perceived Ease of Use (Y2) which does not have a significant effect on Perceived Usefulness (Y1). The overall result also showed that Edmodo can be accepted by users as a reference in education, especially at the university level.
\end{abstract}

Keywords-E-Learning, Edmodo, Technology Acceptance Model 2, user acceptance perception.

\section{INTRODUCTION}

Electronic-based learning media (E-learning) is essential in the industrial revolution 4.0 era for the advancement of education [1]. The industrial revolution 4.0 is a rapid transformation of technological progress in the sector of education, management, and information technology [2]. The revolution can advance the education by taking into account new learning, tools, and resources for students [3]. The impact of industrial revolution 4.0 on education is

\footnotetext{
${ }^{1}$ Randy Pradana Kushatmaja is with Departement of Business and Management Technology, Institut Teknologi Sepuluh Nopember, Surabaya, Indonesia. E-mail: kushatmaja@gmail.com.

${ }^{2}$ Erma Suryani is with Departement of Information System, Institut Teknologi Sepuluh Nopember, Surabaya, Indonesia. E- mail: erma.suryani@gmail.com.
}

information technology-based education as a medium between teachers and students [4].

E-learning provides a more integrated learning function between teachers and students, so that the teaching and learning process can be controlled remotely. Electronicbased learning (E-learning) such as the Edmodo platform has a significant role to support education at the university level [5]. The Edmodo platform was chosen by the researchers because most students in developed and developing countries use the platform as a medium of discussion [6]. Edmodo allows students to learn through computers online without having to meet face-to-face in a classroom [7]. Using Edmodo, it is expected that the university can limit the access space between teachers and students in the class. Thus, teachers and students can send notes, links, announcements, and assignments to each other in a safe and comfortable zone [8].

Another reason the researchers chose Edmodo is that it is the most effective User Generated Content (UGC) to directly represent the perceptions of users [9]. Many universities in developing countries like Indonesia have used Edmodo as a learning medium. Ciputra University was chosen by the researchers because it is one of the universities that follows the technological development. However, it needs to be tested and measured directly to see the perceived ease of use and benefits from Edmodo. According to Hamidi [10], Edmodo is considered to be the most ideal platform for online learning strategies if applied to universities with informatics technology faculties [11].

Figure 1. represents that the Edmodo platform is managed by the Ciputra University as an online learning medium. The platform is expected to provide positive benefits and impacts to increase student interest in learning. Positive impact represents user satisfaction from the use of newly implemented technology [12]. Edmodo is often referred to as a platform which can give full confidence in the ability of students who have control over remote access [13]. The remote control function is to monitor and measure understanding and regulate the learning direction of students [14].

Perceived acceptance from users regarding Edmodo can be measured using the Technology Acceptance Model (TAM) method [15]. TAM is the most suitable method in measuring the level of acceptance of new technologies used by users [16]. 
The TAM method has several construct variables which can be adjusted in accordance with the needs of researchers [17], and are considered to be the best in explaining user behavior towards an information technology system [18].

Previously, Dewi Ayu [19] conducted a study to measure the perceptions of acceptance and the ease of use of Parking Information System (PARIS) using the TAM 1 method. Other researchers [20], also conducted a study on the perception of users in education based on Mobile Learning (M-learning) with the TAM 2 method. Estrieganaa [21], conducted research on virtual laboratory using the TAM 3 method.

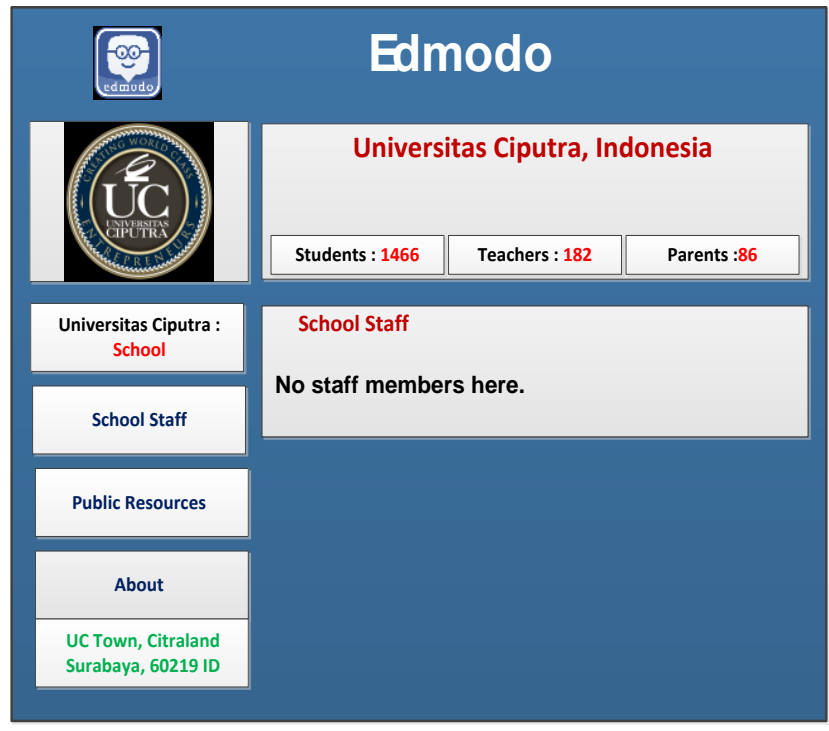

Figure 1. Edmodo platform at Ciputra University, Indonesia

The TAM 1 method has 5 constructs with variables from each construct that are considered to not be able to answer the overall research problems. TAM 2 consists of 11 constructs that are considered to be the most suitable in analyzing the adoption of user acceptance based on construct variables [22]. The TAM 3 method has 17 constructs and focuses on E-commerce which are seen based on the contract variables.

The constructs in TAM 2 focus on explanatory research to measure the perception of user acceptance with quantitative approach [23]. TAM 2 consists of dependent, independent, and moderating variables. The independent variables are subjective norm, image, job relevance, output quality and result demonstrability; the dependent variables are perceived usefulness, perceived ease of use, intention to use, and usage behavior; and the moderating variables are experience and voluntariness [20]. Moderating variables are optional so that in this study voluntariness was not tested because the Edmodo platform is a mandatory platform used during the learning process at Ciputra University, Indonesia. Therefore, the variables used in this study were only 10 constructs. The statement of variables from TAM 2 were used by the researchers as hypotheses to be tested.
The TAM 2 method was chosen because the variables used were able to be adjusted in order to answer the research problems. In addition, this study refers to other researchers [20], which have proven to be predictive in measuring perceptions of acceptance of new technology using TAM 2. However, the previous study merely focused on M-banking so the researchers would like to test on another focus, namely E-learning.

This study used survey as data collection by distributing questionnaires online using Google Forms [15]. The selected respondents were active students of the year of 2018 from various departments at Ciputra University, Indonesia. The data analyzed were obtained from 94 respondents by taking a system error rate of $10 \%$ using the Slovin formula. The data were then processed using the SPSS 23 software [24].

The SPSS software was chosen because it is able to process data statistically to test validity (using Spearman) and reliability, variable descriptive, correlation (using Spearman) and regression. The researchers also calculated the indirect effect and total influence of the result. The hypotheses were tested based on the statistical data processing. The hypothesis test was used as the conclusion to determine the factors which have a significant and insignificant effect.

The result indicated that the relationship of the highest indicator with a value of 35\% is on the Output Quality (X4) which had a significant effect on Perceived Usefulness (Y1); the lowest indicator has a value of $3.1 \%$ on the Perceived Ease of Use (Y2) which does not have a significant effect on Perceived Usefulness (Y1). The overall result also showed that Edmodo can be accepted by users as a reference in education, especially at the university level.

Therefore, this study is expected to be an input for the university to identify user perceptions globally and be able to improve the teaching and learning process effectively in the industrial revolution 4.0 era

\section{LITERATUR REVIEW}

The user perspective can be measured using the appropriate method, namely the Technology Acceptance Model (TAM) [15]. The TAM method has several construct variables that can be adjusted in accordance with the needs of researchers [17], such as the Edmodo platform that can support learning [10] at Ciputra University. Previously, Scherer [23] has measured the user perspective in the field of education using the TAM 2 method.

Other researchers [20] also conducted research on the perspective of users in the field of education based on Mobile Learning (M-learning) with the TAM 2 method; however, the researchers would like to focus on using Elearning at the university level in the industrial revolution 4.0 era $[1]$. 
Online survey was chosen to collect data which were then processed using the SPSS tool [15]. Data were determined by the object of the study [18]. The researchers calculated the population and sample by stratified random sampling proportional [19]. The variables used were selected based on the Technology Acceptance Model 2 (TAM 2) method by defining operational variables for statements in the questionnaire [20]. The questionnaire was distributed to 94 respondents using the Slovin formula with a system error rate of $10 \%$. The result was tabulated using Microsoft Office Excel and processed using SPSS version 23. The data were then tested in terms of the validity and reliability [19].

According to Taherdoost [22], respondent data must be tested with descriptive analysis, correlation and regression, and calculated the direct and indirect effects using path diagrams (based on the regression test). The hypotheses must be tested to measure the assumptions of users as the decision making for conclusions of the result.

\section{METHODOLOGY}

The following the description of theories related to the study.

\section{A. Data Collection}

The data source of this study was divided into primary and secondary data [19]. The primary data were obtained directly from respondents through online questionnaire using Google Forms. The secondary data were obtained from the data recapitulation of the students at Ciputra University, Indonesia. The questionnaire was arranged based on a list of statements on TAM 2 of which variables had been adjusted by the researcher. The questionnaire is confidential, so that the respondent data would not be published. The data analyzed were obtained from 94 respondents by taking a system error rate of $10 \%$ using the Slovin equation [24].
$n=\frac{N}{N(e)^{2}+1}$

In Equation (1), it is represented that $n$ is the sample size and $N$ is the population size (obtained from the total active students of 1466 students for the year of 2018 at Ciputra University, Indonesia); $e$ is the tolerable percentage of error.

The respondents were active students of the year of 2018 from various departments, namely Accounting (5 students), Business Information Systems (4 students), International Business Management (37 students), Culinary Business (1 student), Fashion Design and Business (2 students), Information and Multimedia Technology (15 students), Interior Architecture (2 students), International and Hospitality Tourism Business (3 students), International Business Management (16 students), Psychology (3 students), and Visual Communication Design (6 students). All data were tabulated using Microsoft Office Excel and processed using the SPSS version 23.

\section{B. Technology Acceptance Model 2 for Education}

This study used a path diagram from the TAM 2 model that represented the sequence of cause and effect relationships among variables [22]. TAM 2 consists of dependent, independent, and moderating variables. The independent variables are subjective norm, image, job relevance, output quality and result demonstrability; the dependent variables are perceived usefulness, perceived ease of use, intention to use, and usage behavior; and the moderating variables are experience and voluntariness [20]. The path diagram on TAM 2 is represented in Figure 2.

Figure 2. represents a path diagram of the TAM 2 method which had been adjusted. Red color represents optional moderator variable; it is due to the fact that the Edmodo platform is mandatory to be used during the lecture period. The researchers used path diagrams to conduct tests based on the sequence of the questionnaire [17]. The questionnaire statement is illustrated in Table 1, in which $\mathrm{X} 1$ is subjective norm.

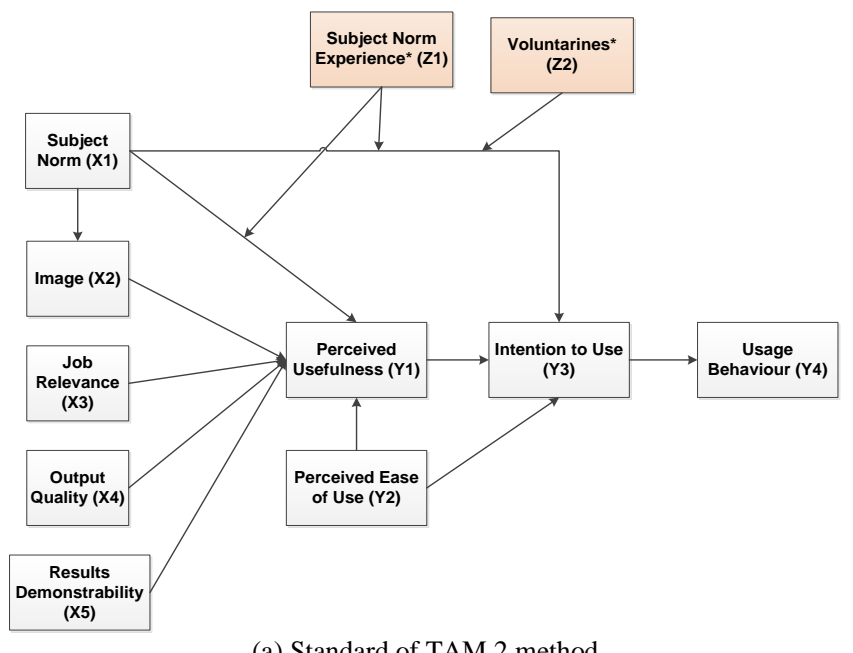

(a) Standard of TAM 2 method 
The $1^{\text {st }}$ International Conference on Business and Management of Technology (IConBMT)

August 3rd 2019, Institut Teknologi Sepuluh Nopember, Surabaya, Indonesia

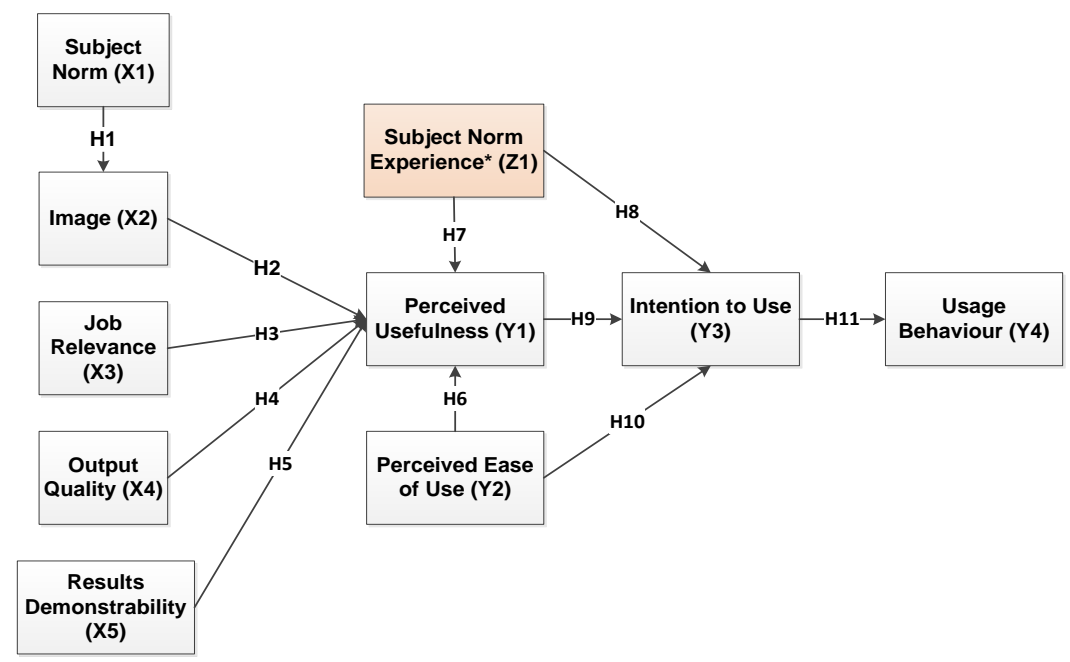

(b) Adjusted TAM 2 method

Figure 2. (a) Standard of TAM 2 method; (b) TAM 2 method adjusted on Edmodo at Ciputra University, Indonesia.

TABLE 1.

ILLUSTRATION OF QUESTIONNAIRE USING TAM 2

\begin{tabular}{|c|c|c|c|c|c|}
\hline \multirow{3}{*}{$\begin{array}{l}\text { Question } \\
\text { Code }\end{array}$} & \multirow{3}{*}{ Subjective Norm Statement } & \multicolumn{4}{|c|}{ Value } \\
\hline & & 1 & 2 & 3 & 4 \\
\hline & & STS & TS & $\mathrm{S}$ & SS \\
\hline $\mathrm{X} 1.1$ & Others affect me to use Edmodo. & & & & \\
\hline $\mathrm{X} 1.2$ & $\begin{array}{l}\text { My close friends make me think } \\
\text { of using Edmodo. }\end{array}$ & & & & \\
\hline
\end{tabular}

The questionnaire was measured using 4-point Likert scale. The purpose of using the Likert scale is to measure qualitative data into quantitative data [19]. Quantitative data were tabulated using Microsoft Office Excel and processed using SPSS version 23. Users were given a score 1 for a statement they feel strongly disagree (STS), score 2 for a statement they feel disagree (TS), score 3 for a statement they feel agree (S), and score 4 for a statement they feel strongly agree (SS) [24]. The questionnaire was distributed to 94 respondents randomly based on the number of samples from each department. The result was tested in terms of the validity and reliability, variable descriptive, correlation and regression, and hypothesis.

\section{Research Variables and Hypotheses on TAM 2}

This study used three variables, namely dependent, independent and moderating variables [20]. The three variables in the Technology Acceptance Model 2 (TAM 2) method have indicators used to test the Edmodo platform at Ciputra University, Indonesia. The description of each variable is described in Table 2. Table 2. was used as the hypotheses of the study. The hypotheses had to be tested in order to prove the validity of the questionnaire prepared by the researchers [16].
Table 3. describes the hypotheses using the TAM 2 method. The hypotheses were prepared by the researchers based on Figure 2 (b).

\section{Validity and Reliability Tests}

To measure the suitability of the questionnaire, the researchers conducted a validity test by measuring each variable indicator. Questionnaire data is valid if the score of the question significantly correlates to the total indicator variable [19]. To calculate the significance of each indicator, the researchers used the equation from Spearman as follows:

$r=\frac{n \sum X Y-\left(\sum X\right)\left(\sum Y\right)}{\sqrt{\left(n \sum(X)^{2}-\left(\sum X\right)^{2}\right)\left(n \sum(Y)^{2}-\left(\sum Y\right)^{2}\right)}}$

The symbol $r$ is the validity coefficient of the variable; $N$ is the number of subjects; $X$ is the value used for comparison among variable indicators; and $Y$ is the instrument of which validity value to be measured. The Spearman test was used because the respondent data were in small samples. Data which did not meet the validation criteria were not used for reliability testing [23].

Reliability test aims to ensure that the questionnaire has a reliable value [20]. The following is the equation from the reliability test:

$\alpha=\frac{\mathrm{k}}{\mathrm{k}-1}\left(1-\frac{\sum \mathrm{sj}^{2}}{\mathrm{sx}^{2}}\right)$

The symbol $k$ is the number of variable indicators; $\sum s j^{2}$ is the number of variances of each variable indicator; $s x^{2}$ is the variance of the overall variable indicators. Data are valid and reliable if the significance value of the variable indicator is more than 0.169 (for 94 correspondents) which refers to $r$ statistic table. 
TABLE 2.

ADJUSTED VARIABLES ON TAM 2

\begin{tabular}{|c|c|c|}
\hline Type of Variable & TAM 2 Variable Indicator & TAM 2 Variable Statement \\
\hline \multirow[t]{11}{*}{ Independent variables } & Subjective Norm (X1) & View of others (X1.1) \\
\hline & & View of experts (X1.2) \\
\hline & Image (X2) & Prestige (X2.1) \\
\hline & & High profile (X2.2) \\
\hline & & Status symbol (X2.3) \\
\hline & Job Relevance (X3) & Importance (X3.1) \\
\hline & & Job relevance $(\mathrm{X} 3.2)$ \\
\hline & Output Quality (X4) & Value (X4.1) \\
\hline & & Obstacle (X4.2) \\
\hline & Result Demonstrability (X5) & Communicating result (X5.1) \\
\hline & & Communicating consequence (X5.2) \\
\hline \multirow[t]{12}{*}{ Dependent variables } & Perceived Usefulness (Y1) & Speed (Y1.1) \\
\hline & & Productivity (Y1.2) \\
\hline & & Effectiveness (Y1.3) \\
\hline & & Information needs (Y1.4) \\
\hline & Perceived Ease of Use (Y2) & Easy to learn (Y2.1) \\
\hline & & Easy to use (Y2.2) \\
\hline & & Easy to understand (Y2.3) \\
\hline & & Easy to obtain information (X2.4) \\
\hline & Intention to Use (Y3) & Interest (Y3.1) \\
\hline & & Prediction (Y3.2) \\
\hline & Usage Behavior (Y4) & Frequency (Y4.1) \\
\hline & & Frequency on similar applications (Y4.2) \\
\hline \multirow[t]{2}{*}{ Moderating variables } & Experience (Z1) & Experience (Z1.1) \\
\hline & & Interesting experience (Z1.2) \\
\hline
\end{tabular}

TABLE 3.

HYPOTHESES USING TAM 2

\begin{tabular}{cl}
\hline \hline Hypothesis & \multicolumn{1}{c}{ Construct Variable on TAM 2 } \\
\hline $\mathrm{H}_{1}$ & It is predicted that subjective norm significantly affects image of Edmodo. \\
$\mathrm{H}_{2}$ & It is predicted that image significantly affects perceived usefulness of Edmodo. \\
$\mathrm{H}_{3}$ & It is predicted that job relevance significantly affects perceived usefulness of Edmodo. \\
$\mathrm{H}_{4}$ & It is predicted that output quality significantly affects perceived usefulness of Edmodo. \\
$\mathrm{H}_{5}$ & It is predicted that result demonstrability significantly affects perceived usefulness of Edmodo. \\
$\mathrm{H}_{6}$ & It is predicted that perceived ease of use significantly affects perceived usefulness of Edmodo. \\
$\mathrm{H}_{7}$ & It is predicted that subjective norm and experience significantly affects perceived usefulness of Edmodo. \\
$\mathrm{H}_{8}$ & It is predicted that subjective norm and experience significantly affects intention to use of Edmodo. \\
$\mathrm{H}_{9}$ & It is predicted that perceived usefulness significantly affects intention to use of Edmodo. \\
$\mathrm{H}_{10}$ & It is predicted that perceived ease of use significantly affects intention to use of Edmodo. \\
$\mathrm{H}_{11}$ & It is predicted that intention to use significantly affects usage behavior of Edmodo. \\
\hline \hline
\end{tabular}

\section{E. Correlation and Regression Tests}

Correlation test aims to determine the causal relationship between two qualitative variables to be transformed into quantitative variables [21]. The following is the equation of the Spearman correlation test:

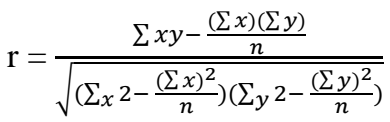


The symbol $r$ is the Spearman's validity coefficient; $x$ and $y$ are independent and dependent variables; and $n$ is the number of samples.

Regression test aims to predict the value of the influence of independent variable on the dependent variable [19]. The following is the equation of the regression test:

$\hat{\mathrm{Y}}=\mathrm{a}+\mathrm{b}_{1} \mathrm{X}_{1}+\mathrm{b}_{2} \mathrm{X}_{2}$

The symbol $\hat{Y}$ is the dependent variable to be predicted; $\mathrm{X} 1$ and $\mathrm{X} 2$ are independent variables; $a$ is the constant value if the independent variables at $\mathrm{X} 1$ and $\mathrm{X} 2$ equal $0 ; b_{1}$ and $b_{2}$ are the regression coefficient value.

\section{RESUlTS AND DISCUSSION}

The result regarding factors that influence the adoption of Edmodo as a learning medium using Technology Acceptance Model 2 (TAM 2) is displayed in the following details:

\section{A. Validity and Reliability Tests}

The validity test used quantitative data in Table 1. calculated using Equation (2). The data were processed using SPSS version 23 to make it easier for the researchers to analyze the valid data. The result is presented in Table 4 .

The data in Table 4. represent the entire questionnaire statements which are considered to be valid or meet the validity requirement. The requirement for validity test is to meet the correlation value between indicator variables, or be more than $r$ table (> 0.169). The indicator on variable X3 has the highest Cronbach's Alpha value; the value of $\mathrm{X} 3.1$ is $0.943^{* *}$, and of X3.2 is $0.957^{* *}$.

High score means that Edmodo is an important platform to use in lecture, so many users agree that the Edmodo platform is important to be used in the learning process at Ciputra University, Indonesia. A two-asterisk symbol (**) is the correlation value on X3.1 meaning that it has a very strong significance value of 0.01 at the $1 \%$ level.

The data in Table 5. indicate that the overall questionnaire statements (indicator variables) are reliable or consistent and trustworthy.

\section{B. Correlation and Regression Analysis}

The valid and reliable result was used in the correlation and regression tests. The correlation and regression tests used the quantitative data in Table 1. using Equation (4).

Table 6. represents the the correlation among variables based on the path diagram of the questionnaire. The path diagram can be seen in Figure 2 (b). The red color on the correlation $\mathrm{Z} 1$ and $\mathrm{Y} 1$ and the correlation $\mathrm{Z} 1$ and $\mathrm{Y} 3$ is considered to be insignificant; meanwhile, the rest indicates a significant result. The result is considered to be insignificant because the correlation value is more than $r$ table $(>0.169)$. The highest value in Table 6 is the correlation between $\mathrm{Y} 3$ and $\mathrm{Y} 4$ of 0.537 .
TABLE 4.

VALIDITY TEST USING SPSS VERSION 23

\begin{tabular}{|c|c|c|c|c|}
\hline Indicator & $\begin{array}{l}\text { Indikator } \\
\text { Code }\end{array}$ & $\begin{array}{l}\text { Correlation of item } \\
\text { to correlation in total }\end{array}$ & $\begin{array}{c}\text { Table } \\
r\end{array}$ & Category \\
\hline \multirow{2}{*}{$\mathrm{X} 1$} & $\mathrm{X} 1.1$ & $0,942^{* *}$ & 0,169 & Valid \\
\hline & $\mathrm{X} 1.2$ & $0,728^{* *}$ & 0,169 & Valid \\
\hline \multirow{3}{*}{$\mathrm{X} 2$} & $\mathrm{X} 2.1$ & $0,718^{* *}$ & 0,169 & Valid \\
\hline & $\mathrm{X} 2.2$ & $0,726^{* *}$ & 0,169 & Valid \\
\hline & $\mathrm{X} 2.3$ & $0,792^{* *}$ & 0,169 & Valid \\
\hline \multirow{2}{*}{$\mathrm{X} 3$} & X3.1 & $0,943^{* *}$ & 0,169 & Valid \\
\hline & $\mathrm{X} 3.2$ & $0,957^{* *}$ & 0,169 & Valid \\
\hline \multirow{2}{*}{$\mathrm{X} 4$} & $\mathrm{X} 4.1$ & $0,752^{* *}$ & 0,169 & Valid \\
\hline & $\mathrm{X} 4.2$ & $0,863^{* *}$ & 0,169 & Valid \\
\hline \multirow{2}{*}{$\mathrm{X} 5$} & X5.1 & $0,930^{* *}$ & 0,169 & Valid \\
\hline & X5.2 & $0,930^{* *}$ & 0,169 & Valid \\
\hline \multirow{4}{*}{ Y1 } & Y1.1 & $0,821^{* *}$ & 0,169 & Valid \\
\hline & Y1.2 & $0,775^{* *}$ & 0,169 & Valid \\
\hline & Y1.3 & $0,733^{* *}$ & 0,169 & Valid \\
\hline & Y1.4 & $0,814^{* *}$ & 0,169 & Valid \\
\hline \multirow{4}{*}{ Y2 } & Y2.1 & $0,784^{* *}$ & 0,169 & Valid \\
\hline & Y 2.2 & $0,781^{* *}$ & 0,169 & Valid \\
\hline & Y 2.3 & $0,817^{* *}$ & 0,169 & Valid \\
\hline & Y2.4 & $0,800^{* *}$ & 0,169 & Valid \\
\hline \multirow{2}{*}{ Y3 } & Y 3.1 & $0,903^{* *}$ & 0,169 & Valid \\
\hline & Y 3.2 & $0,936^{* *}$ & 0,169 & Valid \\
\hline \multirow{2}{*}{ Y4 } & Y4.1 & $0,832^{* *}$ & 0,169 & Valid \\
\hline & Y 4.2 & $0,857^{* *}$ & 0,169 & Valid \\
\hline \multirow{2}{*}{$\mathrm{Z} 1$} & $\mathrm{Z} 1.2$ & $0,886^{* *}$ & 0,169 & Valid \\
\hline & $\mathrm{Z} 1.2$ & $0,709^{* *}$ & 0,169 & Valid \\
\hline
\end{tabular}

TABLE 5.

RELIABILITY TEST USING SPSS VERSION 23

\begin{tabular}{ccccc}
\hline \hline Indicator & $\begin{array}{c}\text { Number of } \\
\text { items }\end{array}$ & $\begin{array}{c}\text { Cronbach's } \\
\text { Alpha }\end{array}$ & Tabel $\boldsymbol{r}$ & Category \\
\hline X1 & 2 & 0,655 & 0,169 & Reliable \\
X2 & 3 & 0,642 & 0,169 & Reliable \\
X3 & 2 & 0,904 & 0,169 & Reliable \\
X4 & 2 & 0,590 & 0,169 & Reliable \\
X5 & 2 & 0,895 & 0,169 & Reliable \\
Y1 & 4 & 0,877 & 0,169 & Reliable \\
Y2 & 4 & 0,852 & 0,169 & Reliable \\
Y3 & 2 & 0,861 & 0,169 & Reliable \\
Y4 & 2 & 0,627 & 0,169 & Reliable \\
Z1 & 2 & 0,548 & 0,169 & Reliable \\
\hline \hline
\end{tabular}


TABLE 6.

CORRELATION TEST USING SPSS VERSION 23

\begin{tabular}{|c|c|c|c|}
\hline No. & Path Diagram & Correlation & Category \\
\hline 1 & $\mathrm{X} 1$ and $\mathrm{X} 2$ & $0,354 * *$ & Significant \\
\hline 2 & $\mathrm{X} 2$ and $\mathrm{Y} 1$ & $0,301^{* *}$ & Significant \\
\hline 3 & $\mathrm{X} 3$ and $\mathrm{Y} 1$ & $0,292 * *$ & Significant \\
\hline 4 & $\mathrm{X} 4$ and $\mathrm{Y} 1$ & $0,524 * *$ & Significant \\
\hline 5 & $\mathrm{X} 5$ and $\mathrm{Y} 1$ & $0,470^{* *}$ & Significant \\
\hline 6 & $\mathrm{Y} 2$ and $\mathrm{Y} 1$ & $0,261^{*}$ & Significant \\
\hline 7 & $\mathrm{Z} 1$ and $\mathrm{Y} 1$ & 0,064 & Insignificant \\
\hline 8 & $\mathrm{Z} 1$ and $\mathrm{Y} 3$ & 0,080 & Insignificant \\
\hline 9 & $\mathrm{Y} 1$ and $\mathrm{Y} 3$ & $0,345^{* *}$ & Significant \\
\hline 10 & $\mathrm{Y} 2$ and $\mathrm{Y} 3$ & $0,477 * *$ & Significant \\
\hline 11 & $\mathrm{Y} 3$ and Y4 & $0,537 * *$ & Significant \\
\hline
\end{tabular}

TABLE 7.

REGRESSION TEST USING SPSS VERSION 23

\begin{tabular}{cccccc}
\hline \hline $\begin{array}{c}\text { Path } \\
\text { Diagram }\end{array}$ & R & T-count & Sig & $\begin{array}{c}\text { R Square } \\
\text { Percentage }\end{array}$ & Category \\
\hline X1 and X2 & 0,339 & 3,462 & 0,000 & $11,5 \%$ & Affected \\
X2 and Y1 & 0,278 & 2,780 & 0,007 & $7,7 \%$ & Affected \\
X3 and Y1 & 0,312 & 3,148 & 0,002 & $9,7 \%$ & Affected \\
X4 and Y1 & 0,591 & 7,034 & 0,000 & $35 \%$ & Affected \\
X5 and Y1 & 0,454 & 8,893 & 0,000 & $20,6 \%$ & Affected \\
Y2 and Y1 & 0,177 & 1,725 & 0,088 & $3,1 \%$ & No effect \\
Y1 and Y3 & 0,319 & 3,233 & 0,002 & $26,4 \%$ & Affected \\
Y2 and Y3 & 0,481 & 5,266 & 0,000 & $23,2 \%$ & Affected \\
Y3 and Y4 & 0,514 & 5,748 & 0,000 & $26,4 \%$ & Affected \\
\hline \hline
\end{tabular}

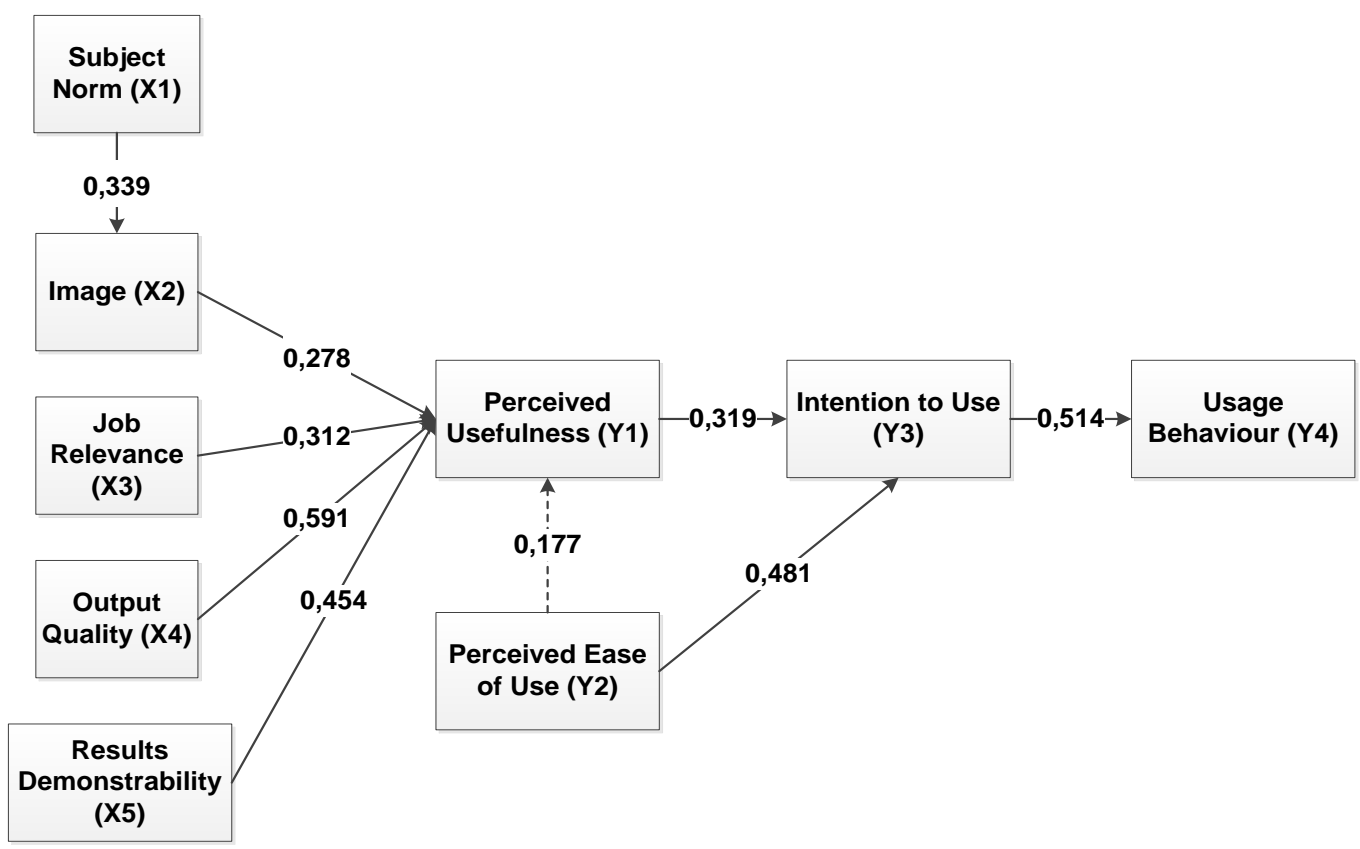

Figure 3. Regression test using TAM 2 adjusted on Edmodo at Ciputra University, Indonesia
The regression in Table 7 . used quantitative data in Table 1, which had been calculated using Equation (5). Correlation Y2 and Y1 is considered to be insignificant (no effect) because the significance value is more than 0.05 . Insignificant data would not be included in the next testing meaning that correlation between Y2 and Y1 (Table 7), Z1 and Y1, as well as Z1 and Y3 (Table 6) would not be processed and analyzed any further. The highest obtained value is in the Output Quality (X4) which significantly affects the Perceived Usefulness (Y1) of 35\%. The highest value is considered to be the most influential on the acceptance of Edmodo adoption at Ciputra University, Indonesia.

\section{Indirect Effect and Total Effect Analysis}

Figure 3. Figure 3 represents the indirect effect and total effect based on TAM 2 (Technology Acceptance Model 2). The path analysis used the data from correlation or relationship (R) in Table 7 . The dashed arrow (---) means weak or no significance, while straight arrow means strong significance among variables.

\section{Hypothesis Analysis}

The hypothesis needs to be tested in order to determine the effectiveness between the questionnaire and the perceptions of users in terms of using Edmodo at Ciputra University, Indonesia. The following is the result of the hypothesis analysis as shown in Table 8. 
The $1^{\text {st }}$ International Conference on Business and Management of Technology (IConBMT)

August 3rd 2019, Institut Teknologi Sepuluh Nopember, Surabaya, Indonesia

TABLE 8.

HYPOTHESIS TESTING USING TAM 2

\begin{tabular}{|c|c|c|c|c|}
\hline Hypothesis & Path diagram of Hypothesis & Result & Sig & Description \\
\hline $\mathrm{H}_{1}$ & Subjective norm (X1) significantly affects image (X2) of Edmodo & 3,462 & ,001 & Ho is rejected and $\mathrm{H}_{1}$ is accepted \\
\hline $\mathrm{H}_{2}$ & Image (X2) significantly affects perceived usefulness (Y1) of Edmodo & 2,780 & ,007 & Ho is rejected and $\mathrm{H}_{1}$ is accepted \\
\hline $\mathrm{H}_{3}$ & Job relevance (X3) significantly affects perceived usefulness (Y1) of Edmodo & 3,148 &, 002 & Ho is rejected and $\mathrm{H}_{1}$ is accepted \\
\hline $\mathrm{H}_{4}$ & $\begin{array}{l}\text { Output quality (X4) significantly affects perceived usefulness (Y1) of } \\
\text { Edmodo }\end{array}$ & 7,034 &, 000 & Ho is rejected and $\mathrm{H}_{1}$ is accepted \\
\hline $\mathrm{H}_{5}$ & $\begin{array}{l}\text { Result demonstrability (X5) significantly affects perceived usefulness (Y1) of } \\
\text { Edmodo }\end{array}$ & 8,893 & 000 & Ho is rejected and $\mathrm{H}_{1}$ is accepted \\
\hline $\mathrm{H}_{6}$ & $\begin{array}{l}\text { Perceived ease of use (Y2) significantly affects perceived usefulness (Y1) of } \\
\text { Edmodo }\end{array}$ & 1,725 & ,088 & Ho is accepted and $\mathrm{H}_{1}$ is rejected \\
\hline $\mathrm{H}_{9}$ & $\begin{array}{l}\text { Perceived usefulness (Y1) significantly affects intention to use (Y3) of } \\
\text { Edmodo }\end{array}$ & 3,233 & ,002 & Ho is rejected and $\mathrm{H}_{1}$ is accepted \\
\hline $\mathrm{H}_{10}$ & $\begin{array}{l}\text { Perceived usefulness (Y1) significantly affect intention to use (Y3) of } \\
\text { Edmodo }\end{array}$ & 5,266 & ,000 & Ho is rejected and $\mathrm{H}_{1}$ is accepted \\
\hline $\mathrm{H}_{11}$ & Intention to use significantly affects usage behavior (Y4) of Edmodo & 5,748 &, 000 & Ho is rejected and $\mathrm{H}_{1}$ is accepted \\
\hline
\end{tabular}

Table 8. presents the result of the accepted and rejected hypotheses. The red color means that the hypothesis is rejected, while the rest means that the hypothesis is accepted. It indicates that the use of Edmodo cannot improve performance, productivity, effectiveness well during the learning process at Ciputra University, Indonesia.

\section{CONCLUSIONS}

The result of the study indicates that the highest value in terms of indicator relationship is between the Result Demonstrability (X4) and Perceived Usefulness (Y1) of $53 \%$; and the lowest is between the Perceived Ease of Use (Y2) and Perceived Usefulness Perception (Y1) of 3.1\%. The result also shows that Edmodo can be accepted by users as a reference in education, especially at the university level. The hypotheses which have a positive or significant effect are $\mathrm{H}_{1}, \mathrm{H}_{2}, \mathrm{H}_{3}, \mathrm{H}_{4}, \mathrm{H}_{5}, \mathrm{H}_{9}, \mathrm{H}_{10}$, and $\mathrm{H}_{11}$ (hypothesis $\mathrm{H}_{6}$ does not meet the regression test requirement, which hypothesis $\mathrm{H}_{7}$ and $\mathrm{H}^{8}$ do not meet the correlation test requirement).

This study is expected to be able to contribute to the Ciputra University in order continuously monitor the user perceptions globally. Therefore, the university can make a decision whether or not to remain implementing the Edmodo platform as a learning medium. Ciputra University is expected to be able to improve the learning process to be more effective in the industrial revolution 4.0 era.

This study can contribute to the Edmodo developers to continue improving the display so that the users find it easier to use (user-friendly). The developers must be updated with information in the industrial 4.0 era, so the users can feel other benefits of using Edmodo (for example, adding new features or collaborating with other platforms).

For future study, it is expected to expand the object and place of research, so that the data are more diverse and complex; the method used must also be more complex and updated than the Technology Acceptance Model 2 method (TAM 2).

\section{REFERENCES}

[1] I. A. Kautsar and R. Sarno, "A supportive tool for project based learning and laboratory based education," Int. J. Adv. Sci. Eng. Inf. Technol., vol. 9, no. 2, pp. 630-639, 2019.

[2] D. Mourtzis, A. Vasilakopoulos, E. Zervas, and N. Boli, "Manufacturing system design using simulation in metal industry towards education 4.0," in Procedia Manufacturing, 2019, vol. 31, pp. 155-161.

[3] M. Elbestawi, D. Centea, I. Singh, and T. Wanyama, "SEPT learning factory for industry 4.0 education and applied research," in Procedia Manufacturing, 2018, vol. 23, pp. 249254.

[4] R. Ladhari and M. Michaud, "eWOM effects on hotel booking intentions, attitudes, trust, and website perceptions," Int. J. Hosp. Manag., vol. 46, pp. 36-45, 2015.

[5] R. Cakır and E. Solak, "Attitude of Turkish EFL learners towards e-learning through tam Model," in Procedia - Social and Behavioral Sciences, 2015, vol. 176, pp. 596-601.

[6] A. A. Holland, "Effective principles of informal online learning design: A theory-building metasynthesis of qualitative research," Comput. Educ., vol. 128, pp. 214-226, 2019.

[7] M. J. Nelson, R. Voithofer, and S. L. Cheng, "Mediating factors that influence the technology integration practices of teacher educators," Comput. Educ., vol. 128, pp. 330-344, 2019.

[8] D. Farjon, A. Smits, and J. Voogt, "Technology integration of pre-service teachers explained by attitudes and beliefs, competency, access, and experience," Comput. Educ., vol. 130, pp. 81-93, 2019.

[9] J. Müller and F. Christandl, "Content is king - But who is the king of kings? The effect of content marketing, sponsored content \& user-generated content on brand responses," Comput. Human Behav., vol. 96, pp. 46-55, 2019.

[10] H. Hamidi and M. Jahanshaheefard, "Essential factors for the application of education information system using mobile learning: A case study of students of the university of technology," Telemat. Informatics, vol. 38, pp. 207-224, 2019.

[11] D. Davis, G. Chen, C. Hauff, and G. J. Houben, "Activating learning at scale: A review of innovations in online learning strategies," Comput. Educ., vol. 125, pp. 327-344, 2018.

[12] D. A. K. Khotimah and R. Sarno, "Sentiment detection of comment titles in booking.com using probabilistic latent 
The $1^{\text {st }}$ International Conference on Business and Management of Technology (IConBMT)

August 3rd 2019, Institut Teknologi Sepuluh Nopember, Surabaya, Indonesia

semantic analysis," in 6th International Conference on Information and Communication Technology, ICoICT 2018, 2018, pp. 514-519.

[13] A. K. Hashim and V. W. Vongkulluksn, "E-Reader apps and reading engagement: A descriptive case study," Comput. Educ., vol. 125, pp. 358-375, 2018.

[14] R. F. Parks, P. B. Lowry, R. T. Wigand, N. Agarwal, and T. L. Williams, "Why students engage in cyber-cheating through a collective movement: A case of deviance and collusion," Comput. Educ., vol. 125, pp. 308-326, 2018.

[15] K. Balasubramanian, V. Jaykumar, and L. N. Fukey, "A Study on 'Student reference towards the use of Edmodo as a learning platform to create responsible learning environment," in Procedia - Social and Behavioral Sciences, 2014, vol. 144, pp. 416-422.

[16] D. J. Lemay, T. Doleck, and P. Bazelais, "Passion and concern for privacy' as factors affecting snapchat use: A situated perspective on technology acceptance," Comput. Human Behav., vol. 75, pp. 264-271, 2017.

[17] J. Lee, J. Kim, and J. Y. Choi, "The adoption of virtual reality devices: The technology acceptance model integrating enjoyment, social interaction, and strength of the social ties," Telemat. Informatics, vol. 39, pp. 37-48, 2019.

[18] Y. Yang and X. Wang, "Modeling the intention to use machine translation for student translators: An extension of Technology
Acceptance Model," Comput. Educ., vol. 133, pp. 116-126, 2019.

[19] D. A. K. Khotimah, V. Nurcahyawati, and M. S. Erstiawan, "Analisis penerimaan penerapan PARIS (Parking Information System) dengan metode Technology Acceptance Model (TAM) pada area parkir Stikom Surabaya," J. JSIKA, vol. 5, no. 6, pp. $1-14,2016$.

[20] M. Al-Emran, V. Mezhuyev, and A. Kamaludin, "Technology Acceptance Model in M-learning context: A systematic review," Comput. Educ., vol. 125, pp. 389-412, 2018.

[21] R. Estriegana, J. A. Medina-Merodio, and R. Barchino, "Student acceptance of virtual laboratory and practical work: An extension of the technology acceptance model," Comput. Educ., vol. 135, pp. 1-14, 2019

[22] H. Taherdoost, "A review of technology acceptance and adoption models and theories," in Procedia Manufacturing, 2018, vol. 22, pp. 960-967.

[23] R. Scherer, F. Siddiq, and J. Tondeur, "The technology acceptance model (TAM): A meta-analytic structural equation modeling approach to explaining teachers' adoption of digital technology in education," Comput. Educ., vol. 128, pp. 13-35, 2019.

[24] S. Sunny, L. Patrick, and L. Rob, "Impact of cultural values on technology acceptance and technology readiness," Int. J. Hosp. Manag., vol. 77, pp. 89-96, Jan. 2019. 